Abstracta Iranicacta Iranica

Revue bibliographique pour le domaine irano-aryen

Volume 34-35-36 | 2017

Comptes rendus des publications de 2011-2013

\title{
James F. Strange. The Archaeology of Judaism from the Persian Period to the Sixth Century AD
}

\section{Astrid Nunn}

\section{(2) OpenEdition}

1 Journals

\section{Édition électronique}

URL : http://journals.openedition.org/abstractairanica/41557

DOI : 10.4000/abstractairanica.41557

ISSN : 1961-960X

Éditeur :

CNRS (UMR 7528 Mondes iraniens et indiens), Éditions de l'IFRI

Référence électronique

Astrid Nunn, « James F. Strange. The Archaeology of Judaism from the Persian Period to the Sixth Century AD », Abstracta Iranica [En ligne], Volume 34-35-36 | 2017, document 29, mis en ligne le 15 juillet 2016, consulté le 27 septembre 2020. URL : http://journals.openedition.org/abstractairanica/41557 ; DOI : https://doi.org/10.4000/abstractairanica.41557

Ce document a été généré automatiquement le 27 septembre 2020.

Tous droits réservés 


\title{
James F. Strange. The Archaeology of Judaism from the Persian Period to the Sixth Century $A D$
}

\author{
Astrid Nunn
}

\section{RÉFÉRENCE}

James F. Strange. " The Archaeology of Judaism from the Persian Period to the Sixth Century AD ", in : Timothy Insoll, ed., Oxford Handbook of The Archaeology of Ritual and Religion. Oxford, 2011, p. 908-920.

1 "The Archaeology of Ritual and Religion" est un Oxford Handbook de 1100 pages. Ce volume est divisé en quatre parties pour approcher le thème gigantesque du rituel et de la religion. La quatrième partie est dédiée aux civilisations anciennes de la Méditerranée et du Proche Orient. L'article cité ici appartient à la cinquième partie sur l'archéologie des grandes religions mondiales que sont le judaïsme, l'hindouisme, le bouddhisme, le christianisme et l'islam. Un paragraphe est dédié au judaïsme de l'époque perse et à la tolérance des rois achéménides. Le matériel archéologique de cette époque consiste en tablettes cunéiformes, sceaux, bulles et en monnaies qui indiquent l'existence d'une petite communauté juive au Levant. 


\section{AUTEURS}

\section{ASTRID NUNN}

Université de Munich 